\title{
The Relationship between Spiritual Intelligence and a Student's Adaptation to College Life: Implications for Social Work Practice
}

\section{Ali M.Abdelmoaty Eldiasty}

Assistant Professor at Social Casework Department Faculty of Social Work, Helwan University, Egypt

\section{Ahmed T. Helal Ibrahim}

Assistant Professor at Social Casework Department Faculty of Social Work, Assiut University, Egypt 



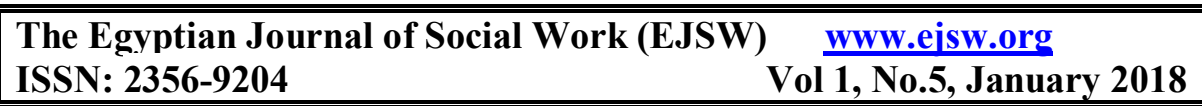

The Relationship between Spiritual Intelligence and a Student's Adaptation to College Life: Implications for Social Work Practice

\author{
Ali M.Abdelmoaty Eldiasty (PhD) \\ Assistant Professor at Social Casework Department \\ Faculty of Social Work, Helwan University, Egypt \\ Ahmed T. Helal Ibrahim (PhD) \\ Assistant Professor at Social Casework Department \\ Faculty of Social Work, Assiut University, Egypt
}

\begin{abstract}
:
Spiritual intelligence is a greatly significant and influential domain in one's personality. It is basically connected with developmental phases, and that is what, indeed, makes it no less important than other intelligence categories. This concept (Spiritual Intelligence) is claimed to be one of the most popular in both human science in general, and social work specifically. Based on this, it is evident that spiritual intelligence has an undeniable effect on a client's social life, and all of its settings, which really necessitates researching it precisely. An additional reason for tackling this concept is scarcity of research emphasizing the role spiritual intelligence can play in education and practice of social work in terms of the Arab environment.

Proportionally, the purpose of the study reported in this article was to identify levels of both spiritual intelligence and adaptation to college life for students at campus, and explore the nature of the relationship between both levels. The study population comprised of $(N=302)$ third-grade students at the School of Social Work, Helwan University, for the academic year 2016-2017. The criteria of validity and the reliability of study tools were met using another subpopulation of $(\mathrm{N}=302)$ participants, which had the same traits as the main study, with the aim of verifying tools' consistency.

The study assumes there is a significant correlation between degrees of spiritual intelligence and adaptation to college life for social work students. As a conclusion, it poses a list of recommendations that can foster professional practice of social workers functioning with university students concerning the impact of spiritual intelligence on their personalities and problems.
\end{abstract}




\section{The Egyptian Journal of Social Work (EJSW) www.eisw.org \\ ISSN: 2356-9204 Vol 1, No.5, January 2018}

Keywords: Spiritual Intelligence - compatibility - university lifeSpirituality

\section{Introduction}

Social work has experienced a wide range of developments which indicate that taking spiritual and religious factors into account when educating and practicing social work is the guarantee that this profession can reach effectiveness with respect to realizing objectives a society anticipates meeting (Ragab, 2000). Primarily, the stereotypical view of social work mainly identified the nature of human personality as merely encompassing biological, psychological and social dimensions. Later, that view developed to concern a client's personality, and included the spiritual dimension when handling his or her troubles (Carroll, 2001).

The early interest in the concept of spirituality began in 1995 when the Council of Social Work Education (CSWE) called for the necessity of incorporating the concepts of spirituality, religion and belief patterns into curricula of social work education as both fundamental constituents and also governing criteria for accrediting educational programs of social work. Later in 1997, the Encyclopedia of Social Work published an article on spirituality in social work by Edward R. Canda (Canda, 1997; Ragab, 2016).

Worthy of mentioning, the primary interest of social sciences in the concept of spirituality started when Abraham Maslow, close to the end of his life, expanded the human needs hierarchy to make it involve a higher level of self-achievement, which was later renamed as self-excellence or self-transcendence. Maslow specifically used the term 'transcendence' to differentiate this kind of person from the dichotomization of self and the environment, stating that it is a person freed from the dichotomous way of thinking,"(Maslow,1968, p.18; Koltko-Rivera, 2006, P302).

Spirituality practice in social work can be looked upon as a therapeutic approach which relies on the efficacy of spiritual and religious values in modifying a client's attitudes and tendentious patterns. Such values function as momentum which utterly repels all forms of human misconduct, and retrieve social stability for an individual, a group and a society so that the highest ranks of maturity and development can be reached (Zedan, Nasr \& Helal, 2016, P57).

Recent years have witnessed an unprecedented concern with the overall comprehension of human nature, a human brain's functions 


\section{The Egyptian Journal of Social Work (EJSW) www.eisw.org \\ ISSN: 2356-9204 Vol 1, No.5, January 2018}

and prospective capacities likely to lead to effective learning. Hence, a human brain has become a top priority of interest by social science scholars and researchers.

Based on this, one of the most dominant skills relevant to the human brain which has always been widely highlighted in the context of educational, psychological and social research, due to its significance, is intelligence (Hamid, 2013, P2). In fact, many theories, especially Gardener's, focus on concerns that human intelligence has more than one type, each of which both form an independent system in itself and occupies a distinct area of the brain. These areas are recognized via radiographic inspection. Accordingly, Gardner introduced eight intelligence forms in his theory, later followed by two others: spiritual and existential. These two latter types emphasize metaphysical issues and human existence. Generally, Gardener's list of Multiple Intelligences included verbal/linguistic, body-kinesthetic, interpersonal, intrapersonal, musical/rhythmic, mathematical/logical, visual-spatial, and natural intelligences (Gardner, H.E, 1993, 1999, 2004, 2006). In relation to this, Buzan indicated that the 21 st century is the real inception of state in which the world transferred from spiritual dimness to revelation, development and spiritual enlightenment, which reflects a universal passion of promoting spiritual intelligence (Buzan 2002, P22).

Gardener, concerning spirituality, suggests that deficiency of spiritual intelligence may drive individuals to experience much suffering. Maladjustment to self and the world along with incompetent realization of relating and connecting things, their surrounding phenomena and reality of existence, are some examples of this deficiency. Accordingly, all these could result sooner-or-later in personality deterioration and low self-esteem (Gardner, H.E, 2000). Several studies have found that emotional intelligence can have a significant impact on various aspects of everyday living. For example; Sonia Sharma (2017) investigated the relationship between spiritual intelligence and adjustments of working women. The main findings of this study signify that there is a significant and negative relationship between spiritual intelligence and adjustment of working women. The working women with a higher level of spiritual intelligence have a higher level adjustment. However, the author found that there is a significant difference found in spiritual intelligence of working women in relation to their age and family system. 


\section{The Egyptian Journal of Social Work (EJSW) www.eisw.org \\ ISSN: 2356-9204 Vol 1, No.5, January 2018}

Hilal Bashir and Liyaqat Bashir (2016) presented a study to explore the relationship between spiritual intelligence and selfregulation among higher secondary school students. They reported that a significant difference was not found between urban and rural students on self-regulation. However, a significant difference was found between urban and rural students on spiritual intelligence.

Additionally, a significant relationship was found between self-regulation and spiritual intelligence of higher secondary school students. Naveen Pant and S.K. Srivastava (2015) compared the level of spiritual intelligence and quality of students life in Haridwar, Uttarakhand (India). They explored the relationship between two variables; gender and educational background, and also sought to identify the difference in quality of life of college students corresponding to gender and educational background. The findings of the study revealed that spiritual intelligence and quality of life related significantly among art students, both male and female. Spiritual intelligence and quality of life also related significantly among science students, male and female. No significant difference was found between male and female students in terms of quality of life. Additionally, no significant difference was found between art and science students in terms of quality of life.

Samyak Makwana (2015) investigated the relationship between spiritual intelligence and job satisfaction of Higher Secondary School teachers. The result of this study indicates that there is a positive relationship between spiritual intelligence and job satisfaction among teachers. However, there is a significant difference found in terms of spiritual intelligence between private and government teachers. There is no significant difference regarding job satisfaction between private and government teachers.

Merial J. Smartt (2014) presented a study to examine the relationship between spiritual intelligence and the achievements of secondary students. The results showed the strength of the relationship between the predictor and control variables of spiritual intelligence, age, gender, and the criterion variable of achievement. The results found a small relationship between a student's self-reported and spiritual intelligence. Also, the result showed that there was not a statistically significant difference between spiritual intelligence and the participants' achievements. 


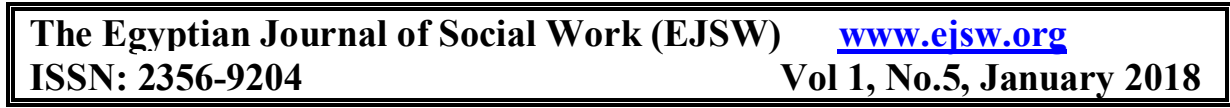

Arbabisarjou et al. (2013) investigated the relationship between various kinds of intelligence and student achievement in the University of Isfahan. They studied the relationship between emotional and spiritual intelligence and how they each relate to student achievement. They reported that it was possible to introduce a model which explains a student's achievement based on their emotional and spiritual intelligences.

Zahra Mahmoudi Kataki et al. (2013) described the effect of spiritual intelligence and psychological capital on the sense of vitality among elementary school teachers in two regions of the city of Esfahan, Iran. The study confirmed that psychological capital and spiritual intelligence have meaningful effects on teachers' personal characteristics.

Rasol Davoudi and Zahra Ataei Zanjani Nezhad (2014) examined the relationship between spiritual intelligence and the creativity of secondary school students. The study reported that a significant correlation was found between spiritual intelligence and the creativity of the students and that an equation could predict the extent that this variable contributed to creativity.

Gail DeBlasio (2012) investigated the relationship between spiritual intelligence and the level of students' social and emotional learning skills in an effort to gain insight into the effect one may have upon the other. The study indicated that there was a significant $(\mathrm{p}<$ .025) predictive relationship between students' self-perceived level of existential well-being and all five scales of the Emotional Quotient Inventory: Youth Version (Intrapersonal, Interpersonal, Adaptability, Stress Management, and General Mood).

Zarina Mat Saad et al. (2010) presented a study about the impact of spiritual intelligence on the health of the elderly in Malaysia. The primary objectives of the study were: (i) to identify the levels of spiritual intelligence and general health of the elderly; (ii) to examine the relationships between spiritual intelligence and health of the elderly; (iii) to examine the differences in the level of spiritual intelligence and health based on selected demographic factors; and (iv) to predict the most dominant dimension of spiritual intelligence that affects health. The findings showed that the majority of respondents were in good health and had excellent spiritual intelligence. It also suggested that spiritual intelligence was positively associated with general health. Those who had higher levels of spiritual intelligence tended to have higher levels of health. 


\section{The Egyptian Journal of Social Work (EJSW) www.eisw.org \\ ISSN: 2356-9204 Vol 1, No.5, January 2018}

Zohar and Marshall defined spiritual intelligence as that through which problems related to significance and values can be assessed and solved. This could be attained through considering life in a broader and richer context. The same researchers indicated that spiritual intelligence expands, examining human behavior with the aim of assessing conduct and lifestyles compared with those of others. Moreover, it highlights activation of both left and right sides of the brain. In short, it combines social and scientific contexts, for it is our ultimate goal in life to find out evidence and clues. Hence, the target of spiritual intelligence is changing the world through serving it (Zohar \& Marshall, 2001). Also, King \& DeCicco described spiritual intelligence as "a set of mental capacities which contribute to the awareness, integration, and adaptive application of the nonmaterial and transcendent aspects of one's existence, leading to such outcomes as deep existential reflection, enhancement of meaning, recognition of a transcendent self, and mastery of spiritual states" (King \& DeCicco, 2009, p. 69).

Frances Vaughan mentioned that "We rely on spiritual intelligence when we explore the meaning of questions such as "Who am I?" "Why am I here?" and "What really matters?" Perhaps spiritual intelligence can also help a person discover hidden wellsprings of love and joy beneath the stress and turmoil of everyday life" (Vaughan, F, 2002, P20).

Richard Wolman (2001) defined spiritual intelligence as "the human capacity to ask ultimate questions about the meaning of life, and to simultaneously experience the seamless connection between each of us and the world in which we live" (Wolman, 2001 pp. 83-84). Additionally, it was defined as "a method enabling an individual to achieve, adjust to life hardships and try to get through or minimize them at the lowest cost". This can be attributed to the point that spiritual intelligence leads to a more profound understanding of one's own self and other individuals. Further, it attempts to better perceive outer surroundings (AlTalaa, 2016).

Others conceptualized it as a mental ability, relying on adaptation and some non-materialistic or metaphysical bases, which may make us more confident and sensitive concerning the essence of life (King, 2008, P56). However, spiritual intelligence is, in terms of Vaughan's perspective, more than a single mental ability. It connects one to God and self to soul. What is more, it surpasses typical psychological development; for it opens hearts, illuminates minds, 


\section{The Egyptian Journal of Social Work (EJSW) www.eisw.org \\ ISSN: 2356-9204 Vol 1, No.5, January 2018}

inspires souls and helps man distinguish between reality and illusion. It also excavates those hidden springs of love and joy lying below accumulated grains of pressures and everyday life troubles. Besides, it just makes us see things as they are in reality with no unconscious distortion. As a result, it is identified in any culture as love, wisdom and service (Vaughan, F, 2002, P18).

Emmons (2000) introduced five principal elements of spiritual intelligence: (a) the ability to transcend from the physical world; (b) the capacity for experiencing upper states of consciousness; (c) the capacity for embracing experiences in daily life; (d) the ability to adopt spiritual resources in problem solving; and (e) the ability to constantly perform moral behaviors (Emmons, R, 2000, P10).

King, 2007 and Lail, 2014 indicated that spiritual intelligence includes five dimensions: (1) Consciousness: i.e. one's distinct mental state which comprises self-realization, self-consciousness, wisdom, rationalism, emotional status, sensory perception, reinforcement of consciousness and soul which involves mindfulness, intuition, silence, praying and dreams, (2) Truth: i.e. ability to live with an open heart and mind, accept others and express love and sympathy for everybody, (3) Grace: which means one's tendency to live in a straight and clear manner and show love and confidence in a life that depends on gratitude, beauty and ecstasy, (4) Transcendence: ability to surpass selfish ego in order to reach perfection and enjoy the qualities of being loved, generosity, respect, mercy and correlation between diversity and distinction, and (5) Meaning: ability to find out about significance of daily activities through simulating service, and facing pain and suffrage (King, 2007 ; Lail, 2014).

Sternberg pointed out that spiritual intelligence involves a combination of analytical, creative and practical faculties. As to analytical faculties, they boost critical existential thinking, personal meaning production and elevated consciousness. Likewise, creative ones function in all spiritual intelligence processes. And finally, practical capacities include adaptive applications, e.g. intended consciousness and consciousness expansion. (Sternberg, 1988, 1997). In a related context, Zohar and Marshall identified seven dimensions of spiritual intelligence, namely Faith, Love, Truth, Compassion, Gratitude, Humility and Inspiration. (Zohar \& Marshall, 2001).

Wilbur. K., 2001 indicated that spiritual intelligence develops according to three stages: 


\section{The Egyptian Journal of Social Work (EJSW) www.eisw.org \\ ISSN: 2356-9204 Vol 1, No.5, January 2018}

- Beginning Stage: in which attention is focused on ego through resorting to-praying, thanking and begging God, so that one may experience tranquility and safety when having personal dilemmas.

- Conventional Stage: (also known as Solidarity Stage) refers to solidarity with religion and transfer from one's self-centered attention to others.

- Post Conventional Level: refers to transfer from commitment to religious and spiritual concepts to a comprehensive tendency towards self-realization and apprehension of various techniques to grasp and experience reality and facts (Wilbur, 2001).

The significance of this study comes from the importance of measuring spiritual intelligence in a student in order to understand his appreciation for the influence of spiritual intelligence on his life and the life challenges he faces. Especially in a society such as Egypt which is strongly influenced by the behavior and values of members of society in religion and spirituality. So it is necessary to understand the student in order to recognize his level of spiritual intelligence and the impact of life challenges on him.

Consequently, the study at hand tried to outline the correlation between spiritual intelligence and attainment of adaptation to college life for social work students.

\section{Objectives of the study}

There are not many studies that examine the relationship between spiritual intelligence and a student's adaptation to college life conducted in Egypt, especially from a social work perspective. Therefore, the present study attempts to: (i) examine the degree of spiritual intelligence of students in Helwan University; (ii) examine degree of adaptation to college life; and (iii) identify relationship between level of spiritual intelligence and that of adaptation to life at campus for the fourth-grade social work undergraduate students at Helwan University.

This study focuses not only on the relationship between spiritual intelligence and a student's adaptation to college life, but also measures the level of spiritual intelligence in the student at the beginning of his studies in order to see whether this influenced him in choosing to study Social Work, or whether his general intelligence played a bigger part in his choice of studies. 


\section{The Egyptian Journal of Social Work (EJSW) www.ejsw.org \\ ISSN: 2356-9204 Vol 1, No.5, January 2018}

\section{Study hypotheses}

- There is a statistically significant correlation between spiritual intelligence and degree of adaptation for the university students (study population).

- There is a statistically significant correlation between some demographical variables (gender, age, dwelling, academic level, grade) and degree of spiritual intelligence for the university students (study population).

- There is a statistically significant correlation between some demographical variables (gender, age, dwelling, academic level, grade) and degree of adaptation for the university students (study population).

\section{Methodology}

The study mainly adopted an analytical descriptive methodology, and was applied at the School of Social Work, Helwan University, Helwan Governorate, Egypt.

\section{Population:}

The survey frame of the Helwan social work students (second, third and fourth grades), after the exclusion of the first-grade students for being juniors, turned out to be 5381. Specifically, the study was applied to a selected sample of third-grade students

In all, population volume, specified in terms of the Proper Sample Volume Law, came to (302) items from a total of 1400 thirdgrade students. Validity and reliability of study tools were verified with dependence on another sample of (100 items), which shared the same traits as the basic study population; so that the valid tools for application can be examined.

Measurement instruments:

Spiritual Intelligence Scale: (SIS) Spiritual Intelligence Scale was primarily developed by Amram \& Dryer in 2007. Later, it was restandardized according to Arab settings by Boshra Ismael Ahmed (2013). This scale contains 45 items. Items are organized on the basis of the 6-point Likert scale (Never or Almost Never, Very Infrequently, Somewhat Infrequently, Somewhat Frequently, Very Frequently, Always or Almost Always). Also, it comprises five key components: Consciousness, Grace, Meaning, Transcendence and Truth. In table (1) is internal consistency validity to this scale with Pearson correlation Coefficient. And in table (2) is Cronbach's alpha coefficient (reliability) 0.89 for the original questionnaire and 0.87 for this current study. 


\begin{tabular}{||lr||}
\hline The Egyptian Journal of Social Work (EJSW) & Www.ejsw.org \\
ISSN: $2356-9204$ & Vol 1, No.5, January 2018 \\
\hline
\end{tabular}

Table (1) - Results of the validity of the Spiritual Intelligence

Scale Using the Pearson Correlation Coefficient $(n=100)$

\begin{tabular}{||c||c||}
\hline $\begin{array}{c}\text { Pearson } \\
\text { correlation } \\
\text { Coefficient }\end{array}$ & Dimension \\
\hline \hline $0.82 * *$ & The first dimension: Awareness \\
\hline \hline $0.80 * *$ & The Second Dimension: Grace \\
\hline \hline $0.62 * *$ & Third Dimension: Meaning \\
\hline \hline $0.78 * *$ & The fourth dimension: excellence \\
\hline \hline $0.68 * *$ & The fifth dimension: the truth \\
\hline \hline
\end{tabular}

The table above shows that most of the coefficients of the variables have a high degree of validity, thus their results are valid, and the tool is finalized.

Table (2) - Results of the Reliability of the Spiritual Intelligence Scale Using the Alpha Cronbach Coefficient and The SpearmanBrown correction $(\mathrm{n}=100)$

\begin{tabular}{|c||c||c||}
\hline $\begin{array}{c}\text { Alpha } \\
\text { Cronbach } \\
\text { Coefficient }\end{array}$ & $\begin{array}{c}\text { The Spearman- } \\
\text { Brown correction }\end{array}$ & Dimension \\
\hline \hline 0.87 & 0.78 & Spiritual Intelligence \\
\hline
\end{tabular}

The table above shows that most of the coefficients of the variables have a high degree of reliability, thus their results are reliable, and the tool is finalized.

Student Adaptation to College Scale: (SACS) was developed by Bohadon Siryk and Robert Baker (1989), and later re-standardized and Arabized by Ali Abd El-Salam (2006). The scale is used to determine and measure student adaptation to college. Moreover, it consists of 36 items divided into four categories: Academic Adaptation (15 Items), Social Adaptation (5 Items), Personal/Emotional Adaptation (8 Items), Attachment/Goal Commitment (8 Items). Each item is rated in terms of a three-point scale (Disagree, Agree and Strongly Disagree with scores 1, 2 and 3 in respective order). Obtained Cronbach's alpha coefficient (reliability) of the genuine questionnaire 0.89 while 0.85 for the study at hand (Ali Abd El-Salam, 2006; Baker, R.E., \& Siryk, B. 1999). 


\begin{tabular}{||lr||}
\hline The Egyptian Journal of Social Work (EJSW) & Www.ejsw.org \\
ISSN: $2356-9204$ & Vol 1, No.5, January 2018 \\
\hline
\end{tabular}

Table (3) - Results of the Reliability of the Student Adaptation to College Scale Using Alpha Cronbach Coefficient and The Spearman-Brown correction $(\mathbf{n}=\mathbf{1 0 0})$

\begin{tabular}{||c||c||c||}
\hline $\begin{array}{c}\text { Alpha Cronbach } \\
\text { Coefficient }\end{array}$ & $\begin{array}{c}\text { The Spearman-Brown } \\
\text { correction }\end{array}$ & Dimension \\
\hline \hline 0.79 & 0.81 & $\begin{array}{c}\text { Student Adaptation to } \\
\text { College }\end{array}$ \\
\hline
\end{tabular}

The table above shows that most of the coefficients of the variables have a high degree of reliability, thus their results are reliable, and the tool is finalized.

\section{Data gathering procedure}

The present study was conducted in the hope of examining the correlation between spiritual intelligence and students' adaptation to the Helwan School of Social Work. The study population included 304 randomly selected third-grade students from the same school. The selection of participants was based on the Purposive Sampling and Simple Random Sample techniques. Data was collected in 2017. Researchers created a form with a cover letter explaining the purposes, confidentiality issues and informed consent to the respondents. Approval was obtained from the students; all participants were then asked to fill in this letter with the study title, nature, and a participant's name. Duration of data collection lasted for about 20 days.

\section{Data Analysis}

Data was scored and analyzed using SPSS 19.0 for Windows software. Descriptive statistical techniques were applied to clarify demographic characteristics of the study sample. Such techniques included Spearman's Rank-Order Correlation Coefficient, whose target is to find out the relevance between two variables (nominal and ordinal); Goodman's and Kruskal's Gamma to explore degree of association for ordinal data; Chi-Square test of Independence to determine if there is significant relationship between two nominal variables; and Cronbach's alpha to assess the reliability of the study tools and measure the strength of the tools' consistency. 


\section{The Egyptian Journal of Social Work (EJSW) www.ejsw.org \\ ISSN: 2356-9204 \\ Vol 1, No.5, January 2018}

\section{Results:}

The general Demographic characteristics of the respondents are summarized in Table 1. Participants included 247 females and 55 males $(81.8 \%$ female \& $18.2 \%$ male).

Table (4) Demographic characteristics of the respondents

\begin{tabular}{|c|c|c|c|}
\hline Percentage & SD & Frequency & Item \\
\hline & & & Gender \\
\hline \multicolumn{2}{|l|}{18.2} & 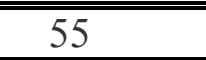 & Male \\
\hline \multicolumn{2}{|l|}{81.8} & 247 & Female \\
\hline \multirow[t]{2}{*}{0.99} & & 20.94 & Age (in year) \\
\hline & & & Marital Status \\
\hline \multicolumn{2}{|l|}{89.1} & 269 & Single \\
\hline \multicolumn{2}{|l|}{10.9} & 33 & Married \\
\hline \multirow{2}{*}{\multicolumn{2}{|c|}{0}} & 0 & Widow/er \\
\hline & & & Place of Residence \\
\hline \multicolumn{2}{|l|}{24.2} & $\overline{73}$ & Countryside \\
\hline \multirow{2}{*}{\multicolumn{2}{|c|}{$7 \overline{75.8}$}} & 229 & Urban \\
\hline & & & Grade \\
\hline 0.7 & & $\overline{2}$ & Excellent \\
\hline 13.2 & & 40 & Very Good \\
\hline 61.9 & & 187 & Good \\
\hline 24.2 & & $\overline{773}$ & Accepted \\
\hline
\end{tabular}

Ages ranged from 18 to 69 years old $(\mathrm{SD}=0.99$, Mean $=$ 20.94). As for marital status, 269 participants were single $(89.1 \%)$ while 33 were married $(10.9 \%)$. Concerning place of residence, 229 participants lived in urban areas $(75.8 \%)$ while 73 came from rural ones $(24.2 \%)$. And as to academic achievement grades, 187 participants got Good (61.9\%), 73 got Accepted (24.2\%), 40 got Very Good (13.2 \%) and 2 got Excellent.

Table (5) The level of spiritual intelligence of the university students $(\mathbf{n}=302)$

\begin{tabular}{||c||c||c|l||}
\hline $\mathrm{M}$ & SD & Range & The first dimension: Awareness \\
\hline \hline 4 & 1.47 & 4.03 & $\begin{array}{l}\text { l listen to my gut feeling or intuition in making } \\
\text { important choices. }\end{array}$ \\
\hline \hline 3 & 1.53 & 4.14 & $\begin{array}{l}\text { I listen deeply to both what is being said and what is } \\
\text { not being said. }\end{array}$ \\
\hline
\end{tabular}




\section{\begin{tabular}{|l|r|}
\hline The Egyptian Journal of Social Work (EJSW) & www.eisw.org \\
ISSN: 2356-9204 & Vol 1, No.5, January 2018 \\
\hline
\end{tabular}}

\begin{tabular}{|c|c|c|c|}
\hline 6 & 1.56 & 3.95 & $\begin{array}{l}\text { In meetings or conversations, I pause several times } \\
\text { to step back, observe, and re-assess the situation. }\end{array}$ \\
\hline 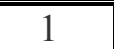 & 1.43 & 4.5 & I look for and try to discover my blind spots. \\
\hline 2 & 1.5 & 4.32 & $\begin{array}{l}\text { I am aware of a wise- or higher-self in me that I } \\
\text { listen to for guidance. }\end{array}$ \\
\hline 5 & 1.49 & 3.98 & $\begin{array}{l}\text { Even in the midst of conflict, I look for and find } \\
\text { connection and common ground }\end{array}$ \\
\hline High & 0.88 & 4.15 & Variable as a whole \\
\hline $\mathrm{M}$ & $\mathrm{SD}$ & Range & The Second Dimension: Grace \\
\hline 3 & 1.59 & 4.52 & $\begin{array}{l}\text { I notice and appreciate the sensuality and beauty of } \\
\text { my daily life. }\end{array}$ \\
\hline 12 & 1.56 & 3.31 & I find ways to express my true self creatively. \\
\hline 2 & 1.34 & 5.023 & My actions are aligned with my values. \\
\hline 9 & 1.69 & 3.83 & $\begin{array}{l}\text { I have a hard time standing firm in my inner truth, } \\
\text { what I know inside to be true. }\end{array}$ \\
\hline 11 & 1.71 & 3.59 & $\begin{array}{l}\text { I have a hard time going against conventions, } \\
\text { expectations, or rules. }\end{array}$ \\
\hline 10 & 1.8 & 3.75 & $\begin{array}{l}\text { Because I follow convention, I am not as successful } \\
\text { as I could be. }\end{array}$ \\
\hline 1 & 1.41 & 5.026 & $\begin{array}{l}\text { My life is a gift, and I try to make the most of each } \\
\text { moment. }\end{array}$ \\
\hline 5 & 1.57 & 4.35 & $\begin{array}{l}\text { I have daily and weekly times set aside for self- } \\
\text { reflection and rejuvenation. }\end{array}$ \\
\hline 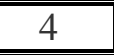 & 1.52 & 4.5 & In my daily life, I am disconnected from nature. \\
\hline 6 & 1.47 & 4.15 & $\begin{array}{l}\text { I am mindful of my body’s five senses during my } \\
\text { daily tasks. }\end{array}$ \\
\hline 8 & 1.51 & 4.00 & $\begin{array}{l}\text { Even when I seem to have very few choices, I feel } \\
\text { free. }\end{array}$ \\
\hline 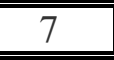 & 1.56 & 4.12 & I bring a feeling of joy to my activities. \\
\hline High & 0.64 & 4.18 & Variable as a whole \\
\hline $\mathrm{M}$ & $\mathrm{SD}$ & Range & Third Dimension: Meaning \\
\hline 1 & 1.5 & 4.64 & I derive meaning from the pain and suffering in my life. \\
\hline 4 & 1.47 & 2.95 & $\begin{array}{l}\text { I see advancing my career as the main reason to do a } \\
\text { good job. }\end{array}$ \\
\hline 2 & 1.52 & 3.56 & My work is in alignment with my greater purpose. \\
\hline 3 & 1.37 & 3.18 & $\begin{array}{l}\text { In my daily life, I feel my work is in service to the } \\
\text { larger whole. }\end{array}$ \\
\hline low & 0.66 & 3.58 & Variable as a whole \\
\hline $\mathrm{M}$ & $\mathrm{SD}$ & Range & The fourth dimension: excellence \\
\hline 4 & 1.56 & 4.4 & $\begin{array}{l}\text { I am aware of a wise- or higher-self in me that I } \\
\text { listen to for guidance. }\end{array}$ \\
\hline
\end{tabular}




\section{\begin{tabular}{|l|r|}
\hline The Egyptian Journal of Social Work (EJSW) & www.eisw.org \\
ISSN: 2356-9204 & Vol 1, No.5, January 2018 \\
\hline
\end{tabular}}

\begin{tabular}{|c|c|c|c|}
\hline 10 & 1.7 & 3.53 & $\begin{array}{l}\text { My goals and purpose extend beyond the material } \\
\text { world. }\end{array}$ \\
\hline 9 & 1.52 & 3.65 & I strive for the integration or wholeness of all things. \\
\hline 8 & 1.41 & 3.7 & $\begin{array}{l}\text { To gain insights in daily problems, I take a wide } \\
\text { view or holistic perspective. }\end{array}$ \\
\hline 6 & 1.61 & 3.98 & $\begin{array}{l}\text { In difficult moments, I tap into and draw on a } \\
\text { storehouse of stories, quotes, teachings, or other } \\
\text { forms of time-proven wisdom. }\end{array}$ \\
\hline 2 & 1.47 & 4.6 & $\begin{array}{l}\text { I have a daily spiritual practice. such as } \\
\text { meditation or prayer. that I draw on to address } \\
\text { life challenges. }\end{array}$ \\
\hline 3 & 1.46 & 4.51 & $\begin{array}{l}\text { I draw on my compassion in my encounters } \\
\text { with others. }\end{array}$ \\
\hline 1 & 1.36 & 4.68 & $\begin{array}{l}\text { I enhance my effectiveness through my } \\
\text { connections and receptivity to others. }\end{array}$ \\
\hline 5 & 1.6 & 4.09 & $\begin{array}{l}\text { In my day-to-day tasks, I pay attention to that } \\
\text { which cannot be put into words, such as } \\
\text { indescribable sensual or spiritual experiences. }\end{array}$ \\
\hline 7 & 1.47 & 3.8 & $\begin{array}{l}\text { I live in harmony with a force greater than } \\
\text { myself, a universal life force, the divine, or } \\
\text { nature, to act spontaneously and effortlessly. }\end{array}$ \\
\hline High & 0.78 & 4.09 & Variable as a whole \\
\hline $\mathrm{M}$ & SD & Range & The fifth dimension: the truth \\
\hline 9 & 1.85 & 3.41 & Being right is important to me. \\
\hline 13 & 1.65 & 3.01 & I want to be treated as special. \\
\hline 5 & 1.59 & 3.82 & $\begin{array}{l}\text { Even when things are upsetting and chaotic around } \\
\text { me, I remain centered and peaceful inside. }\end{array}$ \\
\hline 12 & 1.57 & 3.13 & $\begin{array}{l}\text { I get upset when things don't go the way I want } \\
\text { them to go. }\end{array}$ \\
\hline 4 & 1.6 & 3.9 & $\begin{array}{l}\text { I don't know how to just be myself in } \\
\text { interactions with others. }\end{array}$ \\
\hline 6 & 1.79 & 3.7 & I am my own worst enemy. \\
\hline 2 & 1.65 & 4.46 & $\begin{array}{l}\text { I hold resentment towards those who have } \\
\text { wronged me. }\end{array}$ \\
\hline 10 & 1.57 & 3.35 & $\begin{array}{l}\text { I strongly resist experiences that I find } \\
\text { unpleasant. }\end{array}$ \\
\hline 8 & 1.62 & 3.6 & $\begin{array}{l}\text { I tend to think about the future or the past } \\
\text { without attending to the present moment. }\end{array}$ \\
\hline 11 & 1.27 & 3.25 & My mind wanders away from what I am doing. \\
\hline
\end{tabular}




\section{\begin{tabular}{|lr|}
\hline The Egyptian Journal of Social Work (EJSW) & www.eisw.org \\
ISSN: 2356-9204 & Vol 1, No.5, January 2018 \\
\hline
\end{tabular}}

\begin{tabular}{|c||r||r||l||}
\hline 7 & 1.55 & 3.6 & I am driven and ruled by fears. \\
\hline \hline 3 & 1.55 & 4.45 & $\begin{array}{l}\text { Iremember to feel grateful for the abundance } \\
\text { of positive things in my life. }\end{array}$ \\
\hline \hline 1 & 1.34 & 5.12 & $\begin{array}{l}\text { I have answered all the questions truthfully and } \\
\text { to the best of my ability. }\end{array}$ \\
\hline Mediun & 0.59 & 3.75 & Variable as a whole \\
\hline Mediun & 0.47 & 4.00 & Scale as a whole \\
\hline
\end{tabular}

The above table indicates that the degree of the university students' spiritual intelligence, including all of its dimensions, is medium. This can evidently be inferred if considering Mean ratio that turned 4.00.

Table (6) The order of the spiritual dimensions of intelligence among university students $(\mathrm{n}=302)$

\begin{tabular}{||c||c||c||l||}
\hline $\mathrm{M}$ & SD & Range & Dimension \\
\hline \hline 2 & 0.88 & 4.15 & The first dimension: Awareness \\
\hline \hline 1 & 0.64 & 4.18 & The Second Dimension: Grace \\
\hline \hline 3 & 0.66 & 3.58 & Third Dimension: Meaning \\
\hline \hline 4 & 0.78 & 4.09 & The fourth dimension: Excellence \\
\hline \hline Medium & 0.59 & 3.75 & The fifth dimension: Truth \\
\hline
\end{tabular}

As shown in the above table, it is clear that the degree of spiritual intelligence for university students is medium $(M=4.00)$. Indicators of this conclusion in terms of order of means pursue the following downward ranking: Grace $(\mathrm{M}=4.18)$, Awareness $(\mathrm{M}=$ 4.15), Excellence ( $M=4.09)$, Truth (3.75) and finally Meaning (3.58).

Table (7) Level of the Student Adaptation to College $(\mathbf{n}=302)$

\begin{tabular}{||c||r||r||l||}
\hline M & SD & Range & The first dimension: Academic Adaptation \\
\hline \hline 3 & 0.59 & 2.51 & I regularly attend lectures. \\
\hline \hline 4 & 0.72 & 1.93 & $\begin{array}{l}\text { I am not satisfied with my academic } \\
\text { level. }\end{array}$ \\
\hline \hline 5 & 0.77 & 2.13 & $\begin{array}{l}\text { My goals and my hopes are clear in my } \\
\text { university study. }\end{array}$ \\
\hline \hline 1 & 0.64 & 2.59 & $\begin{array}{l}\text { I feel loss of my motivation for the } \\
\text { continuation of my university study } \\
\text { recently. }\end{array}$ \\
\hline \hline
\end{tabular}




\begin{tabular}{||lr||}
\hline The Egyptian Journal of Social Work (EJSW) & www.eisw.org \\
ISSN: 2356-9204 & Vol 1, No.5, January 2018 \\
\hline
\end{tabular}

\begin{tabular}{|c|c|c|c|}
\hline 10 & 0.73 & 1.9 & $\begin{array}{l}\text { I am satisfied with my university } \\
\text { courses. }\end{array}$ \\
\hline 6 & 0.8 & 2.11 & $\begin{array}{l}\text { I enjoy writing down my university } \\
\text { lectures. }\end{array}$ \\
\hline 14 & 0.62 & 1.54 & $\begin{array}{l}\text { I continue to visit the university library } \\
\text { to seek information. }\end{array}$ \\
\hline 15 & 0.68 & 1.43 & $\begin{array}{l}\text { I participate in seminars and scientific } \\
\text { conferences held by the University. }\end{array}$ \\
\hline 13 & 0.76 & 1.62 & I keep a memoir about university life. \\
\hline 11 & 0.75 & 1.68 & $\begin{array}{l}\text { I find many difficulties in doing } \\
\text { homework at home. }\end{array}$ \\
\hline 12 & 0.61 & 1.62 & $\begin{array}{l}\text { I have some difficulties in doing some } \\
\text { academic courses. }\end{array}$ \\
\hline 2 & 0.66 & 2.52 & $\begin{array}{l}\text { I like courses that are of a practical } \\
\text { nature. }\end{array}$ \\
\hline 7 & 0.78 & 2.03 & $\begin{array}{l}\text { I have friendly relations with some } \\
\text { faculty members of the university. }\end{array}$ \\
\hline 8 & 0.7 & 1.95 & $\begin{array}{l}\text { I disagreed with some colleagues on } \\
\text { some scientific issues. }\end{array}$ \\
\hline Medium & 0.29 & 1.99 & Variable as a whole \\
\hline $\mathrm{M}$ & SD & Range & The Second Dimension: social Adaptation \\
\hline 1 & 0.69 & 2.38 & $\begin{array}{l}\text { I meet many students, and I am trying } \\
\text { to make friends with them. }\end{array}$ \\
\hline 2 & 0.62 & 2.35 & I am compatible with university life. \\
\hline 4 & 0.83 & 1.93 & $\begin{array}{l}\text { I am committed to the sports, cultural and } \\
\text { recreational activities within the university. }\end{array}$ \\
\hline 3 & 0.89 & 2.04 & $\begin{array}{l}\text { I find it difficult to spend my leisure } \\
\text { time within the university. }\end{array}$ \\
\hline 5 & 0.64 & 1.59 & $\begin{array}{l}\text { I feel different from some of my } \\
\text { classmates in some of the ideas and } \\
\text { actions they do. }\end{array}$ \\
\hline Medium & 0.39 & 2.06 & Variable as a whole \\
\hline M & SD & Range & $\begin{array}{l}\text { Third Dimension: Personal / Emotional } \\
\text { Adaptation }\end{array}$ \\
\hline 6 & 0.7 & 1.76 & $\begin{array}{l}\text { Sometimes I feel tense and moody at } \\
\text { college. }\end{array}$ \\
\hline 3 & 0.82 & 2.17 & $\begin{array}{l}\text { I feel incompatibility in working } \\
\text { relationships with the opposite sex. }\end{array}$ \\
\hline 2 & 0.82 & 2.21 & $\begin{array}{l}\text { I feel emotional instability in my } \\
\text { relationship with the opposite sex. }\end{array}$ \\
\hline
\end{tabular}




\section{\begin{tabular}{|lr|}
\hline The Egyptian Journal of Social Work (EJSW) & www.ejsw.org \\
ISSN: 2356-9204 & Vol 1, No.5, January 2018 \\
\hline
\end{tabular}}

\begin{tabular}{|c|c|c|c|}
\hline 1 & 0.52 & 2.71 & $\begin{array}{l}\text { I try to rely on myself to solve the } \\
\text { problems that confront us within the } \\
\text { university. }\end{array}$ \\
\hline 8 & 0.68 & 1.41 & $\begin{array}{l}\text { I rely on some colleagues to solve } \\
\text { some emotional problems with the } \\
\text { opposite sex }\end{array}$ \\
\hline 4 & 0.85 & 2.01 & $\begin{array}{l}\text { I am convinced of the role of the } \\
\text { psychological services center within } \\
\text { the university in guiding students. } \\
\end{array}$ \\
\hline 7 & 0.79 & 1.61 & $\begin{array}{l}\text { Sometimes I have trouble sleeping } \\
\text { when thinking about my future after the } \\
\text { end of my university study. }\end{array}$ \\
\hline 5 & 0.7 & 1.93 & $\begin{array}{l}\text { I feel unable to concentrate and arrange } \\
\text { my thoughts. }\end{array}$ \\
\hline Medium & 0.38 & 2.00 & Variable as a whole \\
\hline M & SD & Range & $\begin{array}{l}\text { The fourth dimension: Commitment to } \\
\text { achieving goals }\end{array}$ \\
\hline 7 & 0.6 & 2.09 & I feel comfortable when I'm in college \\
\hline 1 & 057 & 2.69 & $\begin{array}{l}\text { I know why I am in college, and what I } \\
\text { want from it. }\end{array}$ \\
\hline 5 & 0.77 & 2.45 & $\begin{array}{l}\text { I believe that I am enrolled in this course } \\
\text { because of my own desire. }\end{array}$ \\
\hline 3 & 0.64 & 2.52 & $\begin{array}{l}\text { I try to achieve my goals through } \\
\text { excellence in my undergraduate studies. }\end{array}$ \\
\hline 8 & 0.73 & 2.00 & $\begin{array}{l}\text { I sometimes feel hesitant about } \\
\text { choosing a course. }\end{array}$ \\
\hline 2 & 0.68 & 2.53 & $\begin{array}{l}\text { I'm trying to rehabilitate myself for the } \\
\text { work that I want after graduation. }\end{array}$ \\
\hline 4 & 0.63 & 2.45 & $\begin{array}{l}\text { I keep all instructions and guidance of } \\
\text { university professors. }\end{array}$ \\
\hline 6 & 0.84 & 2.19 & $\begin{array}{l}\text { I hope to continue to complete my } \\
\text { postgraduate studies after graduating } \\
\text { from university. }\end{array}$ \\
\hline High & 0.36 & 2.36 & Variable as a whole \\
\hline Medium & 0.34 & 2.08 & Scale as a whole \\
\hline
\end{tabular}

The table indicates that the degree of the university students' adaptation to college life, including all of its dimensions, is medium. This can evidently be inferred if considering Mean ratio that turned 2.08 . 


\begin{tabular}{||lr||}
\hline The Egyptian Journal of Social Work (EJSW) & www.eisw.org \\
ISSN: 2356-9204 & Vol 1, No.5, January 2018 \\
\hline
\end{tabular}

Table (8) The order of the Student Adaptation to College ( $n=302)$

\begin{tabular}{||c||r|r||l||}
\hline $\mathrm{M}$ & SD & Range & \multicolumn{1}{c||}{ Dimensions } \\
\hline \hline 4 & 0.29 & 1.99 & The first dimension: Academic Adaptation \\
\hline \hline 2 & 0.39 & 2.06 & The Second Dimension: Social Adaptation \\
\hline \hline 1 & 0.38 & 2.00 & $\begin{array}{l}\text { Third Dimension: Personal / Emotional } \\
\text { Adaptation }\end{array}$ \\
\hline \hline Medium & 0.34 & 2.08 & Dimensions as a whole \\
\hline \hline
\end{tabular}

As shown in the above table, it is clear that the degree of adaptation to college life for university students is medium $(M=2.08)$. Indicators of this conclusion in terms of order of means pursue the following downward ranking: Commitment to Achieving Goals $(\mathrm{M}=$ 2.36), Social Adaptation ( $\mathrm{M}=2.06)$, Personal / Emotional Adaptation $(\mathrm{M}=2.00)$, and finally Academic Adaptation (1.99).

Table (9) The relationship between spiritual intelligence and the level of Student Adaptation to College $(n=302)$

\begin{tabular}{|c|c|c|c|c|c|}
\hline $\begin{array}{l}\text { Dimensions } \\
\text { as a whole }\end{array}$ & $\begin{array}{c}\text { Commitment } \\
\text { to Achieving } \\
\text { Goals }\end{array}$ & \begin{tabular}{|l|} 
Personal / \\
Emotional \\
Adaptation \\
\end{tabular} & $\begin{array}{c}\text { Social } \\
\text { Adaptation }\end{array}$ & $\begin{array}{l}\text { Academic } \\
\text { Adaptation }\end{array}$ & \\
\hline $0.122^{*}$ & $0.118 * *$ & 0.061 & 0.091 & 0.72 & Awareness \\
\hline $0.206 * *$ & $0146 * *$ & $0.156 * *$ & $0.191 * *$ & $0.147 *$ & Grace \\
\hline 0.091 & $0.131^{*}$ & 0.013 & 0.027 & 0.94 & Meaning \\
\hline $0.115^{*}$ & 0.111 & 0.058 & 0.062 & 0.7 & Excellence \\
\hline $0.221 * *$ & $0.118 * *$ & $0.188 * *$ & $0.189 * *$ & $0.184 * *$ & Truth \\
\hline $0.253 * *$ & $0.194 * *$ & $0.154 * *$ & $0.198 * *$ & $0.188 * *$ & $\begin{array}{l}\text { Dimensions } \\
\text { as a whole }\end{array}$ \\
\hline
\end{tabular}

Note. $* \mathrm{p}<.05 . * * \mathrm{p}<.01$ or $*$ Significant at 0.05 level, $* *$ Significant at 0.01 level

This table establishes the conclusion that there is a statistically positive correlation, significant at 0.01 , between spiritual intelligence as a whole and degree of adaptation to college life, including all of its dimensions, for university students. This, proportionally, forces us, as researchers, to take the first hypothesis which states "There is a statistically significant positive correlation between spiritual intelligence and the degree of adaptation to college life for students 'study population"", for granted. Nevertheless, it was found that this same statistically positive correlation among some marginal dimensions was not significant. This can be accounted for by the possibility that other variables, which were not highlighted in this 


\section{The Egyptian Journal of Social Work (EJSW) www.eisw.org \\ ISSN: 2356-9204 Vol 1, No.5, January 2018}

study, such as handling social networking sites and social upbringing, may be more significant and profoundly influence spiritual intelligence. This apparently reflects how vital it is to make use of integral methodology. In other words, it is a must to keep a balanced perspective when considering interactive variables.

\section{Discussion}

This paper attempts to advance the empirical study of linking spiritual intelligence and student adaptation to college life. Spiritual intelligence has been reported to have positive impacts on Academic Adaptation, Social Adaptation, Personal / Emotional Adaptation, and Commitment to Achieving Goals.

In the present study, we attempted to bridge the gap in social work literature, namely with respect to spiritual intelligence and its relationship to students' adaptation to the college environment. In pursuing this objective, two tools, namely the Spiritual Intelligence Scale and the Student Adaptation to College Scale, were applied to a population of 302 university students.

Our results show that spiritual intelligence according to the study sample was generally medium. The average of the study sample on the spiritual intelligence scale was 4.00 , and the standard deviation was 0.47 . The results also showed that the responses of the study sample in the sub-dimensions of the scale were high in Awareness, Grace, and Excellence, low in the Meaning dimension, and medium in the Truth dimension. This indicates Higher spiritual intelligence scores for the study sample.

The present study also found that the Student Adaptation to College life, according to the study sample, was generally medium. The average of the study sample on the Student Adaptation to College life scale was 2.08, and the standard deviation was 0.34 . The results of the study described that the responses of the study sample in the subdimensions of the scale were medium in all the scale dimensions; Academic Adaptation, Social Adaptation, Personal /Emotional Adaptation and, Commitment to achieving goals. This indicates Higher Student Adaptation to College life scores for the study sample.

The present study also showed that the first hypothesis, assuming there is a statistically significant positive correlation between spiritual intelligence and degree of adaptation to college life, including marginal hypotheses, was verified. These findings are consistent with previous studies (Sonia Sharma, 2017; Hilal Bashir and Liyaqat Bashir, 2016; Naveen Pant and S.K. Srivastava, 2015; 


\section{The Egyptian Journal of Social Work (EJSW) www.ejsw.org \\ ISSN: 2356-9204 Vol 1, No.5, January 2018}

Samyak Makwana, 2015; Rasol Davoudi and Zahra Ataei Zanjani Nezhad, 2014; Arbabisarjou et al., 2013; Rasol Davoudi and Zahra Ataei Zanjani Nezhad, 2014; Gail DeBlasio 2012). These studies have demonstrated a statistically significant positive correlation between spiritual intelligence and many other issues such as adjustments of working women; self-regulation among higher secondary school students; quality of life of college students; and job satisfaction; student achievement and creativity of secondary school students.

Notably, no other past social work study, in the context of Arab social work, (as far as the researchers are concerned) investigated spiritual intelligence. Yet, other various researchers in closely related disciplines such as psychology, psychiatry, well-being, and nursing did so. Having this in mind, this study comes to be the first Arab research effort, regarding social work, which handles spiritual intelligence.

\section{Implications for social work practice}

The importance of spiritual intelligence in predicting the adaptation of students to university life has been highlighted. In the present study, it is shown that the dimensions of Grace and Truth strongly influence the students achieving adaptation to university life compared with other dimensions. For that reason, the findings of this research have useful academic and practical implications not only for the student but most importantly for social workers, especially social workers working with university youth.

Our findings clearly indicate that there is a statistically significant positive correlation between spiritual intelligence and adaptation to college life for students, which necessitates paying due attention by both academics and social workers to this spectrum of intelligence when conducting professional interventions with clients in all social work settings. As a result, the study recommends:

1. Conducting a great deal of research concerning spiritual intelligence of various age sections. The target beyond this is to design counseling programs aimed at promoting spiritual intelligence of society members. Relatively, it is highly recommended to design therapeutic programs tackling problems which result from a decline in spiritual intelligence. This should also include more focus on those who badly need to develop this type of intelligence. 


\section{The Egyptian Journal of Social Work (EJSW) www.ejsw.org \\ ISSN: 2356-9204 Vol 1, No.5, January 2018}

2. Setting a series of training courses, whose target audience would include youths, staff functioning at social institutions and university officials, on spiritual intelligence development.

3. Incorporating a Spiritual Intelligence Scale into the inventory of social and psychological tests, authorized at accredited hospitals and centers.

4. Social work students should be exposed to training in spiritual intelligence in the practical field and be trained under the supervision of Specialized practitioners. This experience would help them deal appropriately with clients who need attention in spiritual intelligence.

5. Incorporating spiritual intelligence among academic undergraduate, graduate and postgraduate programs and in the social work curricular syllabus, for the significance and impact this intelligence has in attaining a client's academic, familial and professional adaptation.

6. Currently the Social Work curriculum does not include the Spiritual intelligence techniques and methods of preparing the student for practical work in the future, so it is necessary to pay attention to teaching the practice of spiritual intelligence in social work.

\section{Study Limitation:}

The study is facing some limitations and as a result future researchers are advised to implement the following suggestions for replicating such types of study.

- A major limitation of this study included sampling bias. The majority of participants were third-grade students at the School of Social Work at Helwan University. Thus, the sample was heavily weighted towards third-grade students, which is not a representative sample of the general Social work student population.

- The area of the sample is limited within Cairo city; it would be suitable if the sample is selected from other districts and cities of the country.

- Study is limited with the exploration; it would be more valuable if the study went with predictive purposes. 
The Egyptian Journal of Social Work (EJSW) www.ejsw.org

ISSN: 2356-9204 Vol 1, No.5, January 2018

\section{Conclusion}

In conclusion, the research showed that spiritual intelligence plays an important role in the adaptation of students to university life. A significant positive correlation was found between spiritual intelligence and student adaptation to college life. Therefore, it could be predicted that increasing spiritual intelligence leads accordingly to growing student adaptation to college settings and vice versa. However, it was found that this same statistically positive correlation among some marginal dimensions was not significant. This can be accounted for in the possibility that other variables, which were not highlighted in this study, such as handling social networking sites and social upbringing, may be more significant and profoundly influence spiritual intelligence. This reflects how vital it is to make use of integral methodology. In other words, it is a must to keep a balanced perspective when considering interactive variables. Nevertheless, future research is recommended at the national level in order to ascertain the generality of this study. 


\begin{tabular}{||l|c|}
\hline $\begin{array}{l}\text { The Egyptian Journal of Social Work (EJSW) } \\
\text { ISSN: } 2356-9204\end{array}$ & www.ejsw.org \\
Vol 1, No.5, January 2018
\end{tabular}

\section{REFERENCES}

Arbabisarjou, A., Raghib, M. S., Moayed, N., \& Rezazadeh, S. S. (2013). Relationship Between Different Types of Intelligence and Student Achievement. Life Science Journal, 10(7s), 128133.

AITalaa, M. E. M. (2016). Spiritual intelligence and its relation to the psychological steadfastness of the students of the Islamic University in Gaza. psychology. Faculty of Education, Islamic University in Gaz. master: 160.

Amram, Y., \& Dryer, D. C. (2007). The development and Preliminary Validation of the Integrated Spiritual Intelligence Scale (ISIS). Institute of Transpersonal Psychology, Palo Alto, CA

Baker, R.E., \& Siryk, B. (1999). Student Adaptation to College Questionnaire Manual. Los Angeles, CA: Western Psychological Services.

Buzan, T. (2002). The Power of Spiritual Intelligence 10 ways to tap into your spiritual genius. New York, HarperCollins Publishers.

Carroll, M. M. (2001). Conceptual Models of Spirituality. Transpersonal Perspectives on Spirituality in Social Work. R. C. Edwards and E. D. Smith. New York, The Haworth Press, Inc: 5-22.

Emmons, R. (2000). Is spirituality an intelligence? Motivation, cognition, and psychology of ultimate concern. The International Journal for the Psychology of Religion, 10(1), 3-26.

Furman, L. D., et al. (2011). "Christian Social Workers' Attitudes on the Role of Religion and Spirituality in U. S. Social Work Practice and Education: 1997-2008." Social Work \& Christianity 38(2): 175-200.

Furman, L. D., et al. (2007). "A Comparative International Analysis of Religion and Spirituality in Social Work: A Survey of UK and US Social Workers." Social Work Education 24(8): 813839.

Gail DeBlasio. (2012). An examination of the spiritual intelligence and social and emotional learning skills of public school students in an urban district. ( $\mathrm{PhD}$ diss.). School of Professional, Western Connecticut State University 


\begin{tabular}{|l|r|}
\hline The Egyptian Journal of Social Work (EJSW) & www.eisw.org \\
ISSN: 2356-9204 & Vol 1, No.5, January 2018 \\
\hline
\end{tabular}

Gardner, H.E. (1993). Multiple intelligences: The Theory in practice. New York: Basic Books.

Gardner, H.E. (2000). A case against spiritual intelligence. The International .Journal for the Psychology of Religion, 10(1), 27-34.

Gardner, H.E. (2004). Frames of mind: The theory of multiple intelligences

Anniversary Edition). New York, NY: Basic Books.

Gardner, H.E. (2006). Multiple intelligences: New horizons (Completely Revised and Updated). New York, NY: Basic Books.

Hamid, N. I. (2013). Spiritual intelligence and its relation to the ways of thinking and some personality traits of university students. Department of Mental Health. Faculty of Education, University of Tikrit. PhD.

Hilal Bashir and Liyaqat Bashir. (2016). Investigating the relationship between self-regulation and spiritual intelligence of higher secondary school students. Indian Journal of Health and Wellbeing, 7(3), 327-329.

Husain, A. and D. R. Hodge (2016). "Islamically modified cognitive behavioral therapy: Enhancing outcomes by increasing the cultural congruence of cognitive behavioral therapy selfstatements." International Social Work 59(3): 393-405.

Husain, A. and M. E. Sherr (2015). "Introduction: Religion and Spirituality in Competency-Based Social Work Practice." Social Work \& Christianity 42(1): 3-6.

King, D. B. (2008). Rethinking claims of spiritual intelligence:A definition, model, and measure. Natural and Social Sciences Program. Faculty of Arts and Science, Trent University. Master of Science.

King, D. B., \& DeCicco, T. L. (2009). A viable model and selfreport measure of spiritual intelligence. International Journal of Transpersonal Studies, 28(1), 68-85.

Kulis S, Hodge DR, Ayers SL, Brown EF, Marsiglia FF. (2012). "Spirituality and religion: intertwined protective factors for substance use among urban American Indian youth." Am J Drug Alcohol Abuse 38(5): 444-449. 


\begin{tabular}{|l|r|}
\hline The Egyptian Journal of Social Work (EJSW) & www.eisw.org \\
ISSN: 2356-9204 & Vol 1, No.5, January 2018 \\
\hline
\end{tabular}

Lail, S. A. A. (2014). Spiritual Intelligence and Relation to Parental, Economic and Social Attitudes of High School Students in the Nazareth Region. psychology. Faculty of Educational and Psychological Sciences, Ajman Arab University. Master.

Merial J. Smartt. (2014). the relationship of spiritual intelligence to achievement of secondary students. (PhD diss.). School of Education, Liberty University.

Naveen Pant and S.K. Srivastava. (2015). Spiritual intelligence, gender and educational background as related to the quality of life of college students. Indian Journal of Positive Psychology, 6(3), 226-232.

Ragab, I. A. (2000). "New Trend in American Social Work Spirituality factors in social work." Modern Muslim 24(96): 217-219.

Ragab, I. A. (2016). "The Islamic perspective on social work: A conceptual framework." International Social Work 59(3): 325342.

Samyak Makwana (2015). Spiritual intelligence and job-satisfaction of higher secondary school's teachers. Indian Journal of Positive Psychology, 6(4), 429-431.

Sonia Sharma. (2017). A study of relationship between spiritual intelligence and adjustment in relation to their age and family system of working women. Indian Journal of Positive Psychology 2017, 8(3), 342-346.

Sternberg, R. J. (1988). Te triarchic mind: A new theory of human intelligence. New York, NY: Viking.

Sternberg, R. J. (1997). Te concept of intelligence and its role in lifelong learning and success. American Psychologist, 52(10), 1030-1037. doi:10.1037//0003-066X.52.10.1030

Wilbur, K. (2001). How straight is the Spiritual path? The Relation of Psychological and Spiritual Growth. In The Eye of the Spirit:

An Integral Vision for a World Gone Slightly Mad Boston: Tambala.

Wolman, R. N. (2001). Thinking with your soul: Spiritual intelligence and why it matters. New York: Harmony Books. 


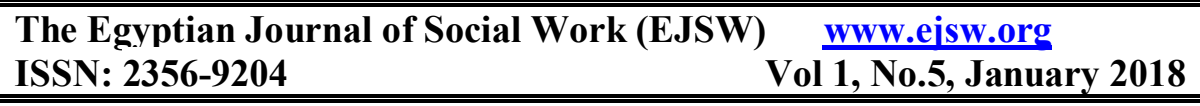

Vaughan, F. (2002). What is spiritual intelligence? Journal of Humanistic Psychology, 42(2), 16-33 (cited by: Amram, J., 2005, Intelligence beyond IQ: The contribution of Emotional and Spiritual Intelligences to Effective Business Leadership, Institute of Transpersonal Psychology, p 1)

Maslow, A.H. (1968). Toward a psychology of being (2nd ed.). New York: Van Nostrand Reinhold.

Koltko-Rivera, M.E. (2006). Rediscovering the later version of Maslow's hierarchy of needs: Self transcendence and opportunities for theory, research, and unification. Review of General Psychology, 10(4), 302-317.

Zedan, A. H., Nasr, A. M., \& Helal, A. T. (2016). Evidence-based practice with individuals and families. Alexandria, Egypt: Modern Office University.

Zohar, D. and I. Marshall (2000). SQ Connecting with our spritiual intelligence. New York, Bloomsbury.

Zahra Mahmoudi Katakia, Fatemeh Rezaeib and Yousef Gorji. (2013). A social work study on the effect of spiritual intelligence and psychological capital on sense of vitality. Management Science Letters 3, 1559-1564. doi: 10.5267/j.msl.2013.05.036.

Zarina Mat Saad, Zulkarnain A. Hatta and Noriah Mohamad. (2010). The Impact of Spiritual Intelligence on the Health of the Elderly in Malaysia. Asian Social Work and Policy Review 4 (2010) 84-97 